Jurnal Ilmu Sosial dan Pendidikan (JISIP)

Vol. 5 No. 3 Juli 2021

Terakreditasi Peringkat 5 (No. SK: 85/M/KPT/2020)

e-ISSN : 2656-6753, p-ISSN: 2598-9944

DOI: 10.36312/jisip.v5i3.2235/http://ejournal.mandalanursa.org/index.php/JISIP/index

\title{
An Analysis Of The Enlightening Values In The Novel Kite Runner By Khaled Hosseini
}

\author{
K. Dedy Sandiarsa $\mathbf{S}^{\mathbf{1}}$, Muhamad Suhaili ${ }^{2}$ \\ ${ }^{12}$ Universitas Pendidikan Mandalika (UNDIKMA) \\ Email: dedysandiarsa@ undikma.ac.id ${ }^{1},{\text { muhamadsuhaili@undikma.ac.id }{ }^{2}}^{2}$
}

\begin{tabular}{l}
\hline Article Info \\
\hline Article history: \\
Article Reseived : 20July 2021 \\
Publication: 20 July 2021 \\
\\
\hline Kata Kunci: \\
$\begin{array}{l}\text { Nilai Moral, Novel Kite } \\
\text { Runner }\end{array}$
\end{tabular}

\section{Article Info}

Article history:

Article Reseived : 20 July 2021

Publication: 20 July 2021

Keyword

Enlightening values, Lite

Runner Novel

\begin{abstract}
Penilitian ini bertujuan untuk menemukan nilai-nilai pendidikan yang berada dalam novel "Kite Runner" oleh Khaled Khosseini.dalam hal ini peneliti menggunakan metode kualitatiif deskriftif. Dalam mengumpulkan data penilitian ini menerapkanempat langkah yaitu dokumentasi, membaca, membaca ulang dan identifikasi. Dalam menganalisa data dalam penilitii menggunakan tiga langkah yaitu pengurangan data, menyajikan data, mengambarakan, menyimpulkan dan membenarkan.ada dua jenis data yang di temukan yaitunilai dalam sendiri dan nilai cara memperlakukan orang lain. Kedua jenis data tersebut menemukan bagianbagiannya data memperlakukan orang lain terdapat dua data yaitu kesetiaan dan kepercayaan, dua kasih sayang dan enam kebaikan persahabatan. Data ditemukan adalah nilai menjadi diri sendiri sebanyak sebelas data dan nilai memberi sebanyak sepiluh data. Ditemukan dua kejujuran, lima keberanian, satusikap tenang dan sabar, dua potensi kepercayaan satu displin and moderasi.

Abstract

This research was aimed to find out the enlightening values of The Kite Runner Novel. The statement of the problem. Was "What were the enlightening values in The Kite Runner Novel. The method on this study was qualitative descriptive. There werefour steps for Techniques of data collection were collective from the novel itself,documentation, reading the novel the kite runner novel was the from the first pages until the last pages. Re-reading and the last is identifying. In analyzing the data, the researcher used three steps, namely data reduction, data display and conclusion and drawing or verification. Those aretwo types of data found, namely values of being and values of giving. The two types of data found the parts of data giving namelytwo loyalties and trustworthy, two loves affection and six kindsof friendly. The data found are values of being with eleven data and values of giving ten data. Found two honesties, five bravely, one peace ability, two confident and potential and one discipline and moderation.
\end{abstract}

This is an open access article under the Lisensi Creative Commons Atribusi-BerbagiSerupa 4.0 Internasional (i) (2)

Corresponding Author:

K. Dedy Sandiarsa $S^{1}$

Universitas Pendidikan Mandalika (UNDIKMA)

Email: dedysandiarsa@undikma.ac.id

\section{INTRODUCTION}

According to Bennet and Royle (2004), literature is the kind of writing which most persistently and most provocatively engages with the uncanny aspects of experience, thought and feeling. It means that literature is an of writing that includes many aspects. Literature can find from many literary works. Moreover, Cuddon (2013) states that literature is a board term that usually denotes 
works that belong to the major genres: epic, drama, lyric, novel, and short story. It tells about for writing study literature has many genres such as drama, novel or short story. Talking about novel, it can be one of the various texts of literary works. Novel has certain messages that are delivered by the author so that the reader gets the abstract experience from the story (Ariyani, 2010: 2). As said by Robert Stanto, novel is a long story that present in detail the development of a character or a large complex social situation or a relationship involving many characters or a complicated even covering many years among a few characters (Stanton, 1965: 44).

According to Nurgiantoro (2012: 23) Novel has two main elements which can be analyzed. Those are intrinsic elements and extrinsic elements. Intrinsic elements are the elements which develop the literary work from inside such as: character, plot, setting, theme and poin of view. Beside the intrinsic elements that build a novel from inside, the extrinsic elements are the elements which build the novel from outside such as, social, enlightening, religion and moral values.

Based on the explanation above the writer is interested in analyzing Enlightening values on the Novel "Kite Runner" by Khaled Hosseini. The "Kite Runner" Novel tells about a friendship of two children from different races and tribes, Amir and Hassan with a background of life in Afghanistan. Perhaps this novel is reputed as a reflection of life condition in Afghanistan at glance. It also provides the portrayal of socio-politics and economic condition that happened in Afghanistan a few years ago.

The writer of this study is interested with this novel because The "Kite Runner" is one of contemporary novel that written by a United State Afghanistan writer. It takes a scene of story in Afghanistan social condition occurred after regime era of Russion invasion. This novel has been translated into 42 languages and sold in 70 countries. This novel also has been adapted to film with the same title in 2007 and became best-seller in the United States.

The reason why the writer take enlightening values to be analyzed because want to know how the enlightening values apply in daily life between lower class people and high class people in this novel. It has different race but they still communicating to each other. Then how are they behave and communicate in practicing in this novel. That's the reason why the writer really interested in analyzing the phenomena.

\subsection{Statement of Problems}

Based on the background of the study, the writer formulated the questions "What are the Enlightening values of the "Kite Runner" Novel by Khaled Hosseni?"

\subsection{The Purpose of the Study}

The purpose of the study to find out the enlightening values on the "Kite Runner" Novel by Khaled Hosseni.

\section{REVIEW OF RELATED LITERATURE}

\subsection{Novel}

Novel is part of literature. Most novels talked about people and their problem, especially the conflict between individual and the society in which they live. In it, the authors express their ideas, imagination, feeling, morality, character, setting etc. Novel is also one of interesting objects for reading. Sometimes, lectures and teachers at some of universities and schools ask their students to read, to understand, and to analyze certain novels and order to extract moral teachings; the students can analyze the moral values of the story especially positive values.

Sumardjo (1998: 29) says that "novel is a story with the prose form in long shape, this long shape means the story including the complex plot, many character and various setting." The novel is the genre of fiction, and fiction may be defined as the art or craft of contriving, through the writer word, representations of human life that instruct or divert or both. The various forms that fiction may take are best seen less as a number of separate categories than as 
a continuum or, more accurately, a cline, with some such brief form as the anecdote at one and of the scale and the longest conceivable novel at the other.

When any piece of fiction is long enough to constitute a whole book, as opposed to a more part of a book, then it may be said to have achieved novel hood. But this state admits of its own quantitative categories, so that a relatively brief novel, may be term a novella (or, if the insubstantiality of the content matches of brevity, a novellete), and a particularly long novel may overflow the banks of the single volume and become a roman-fleuve or river novel. It all means that length is very much one of the dimensions of the genre.

\subsection{Enlightening Values}

Enlightening is human effort to create their personals equivalent with the sacral and cultural values (Noo Syam, 1983: 3). Futhur (1985: 2) said that in reality the enlightening value is a human effort to continue itself.

Value in terms of social context is really prestigious as a reflection of human's activities regarding their interaction with people in a certain context such as: religion, etc, Stone, et, al,. (2004: 197) said that the value placed in literacy is reflected in and interacts with many of the other variables. For example, the value is literacy depends of the purposes serves within a particular society, which in turn interact with and shape parental attitudes towards literacy, whether and how children are engaged and literate activities. Furthermore, Gardner-Chloros (2009: 174) stated the values and attitudes are about the appropriate use of the language in society at large.

Moreover, West, (1980: 3) in one topic his research in education wrote about enlightening value that the best way of the people in recognizing himself and also recognizing the elements outside or his environment. He further stated the human beings at the unique product of their life, the more highly developed sound nervous system has an able them to develop sound and symbol (letter and number) that make the possible the communication and recording or their questions, observation, experiences and idea, they are successfully acquired by human being as a result of their knowledge searching which in commonly stated by the eminent as enlightening system. In a wider description it is understand able that the humans greater curiosity, implemented by the control.

Regarding the religious aspect as what the writer in this study wants to explore complained that gradually people began to see that the operation of the forces of the nature were not as they had been led to believe, they began to observe orderliness in this universe.

Value can be separated from education, because value is closely related the good or bad case. Things depend on values implied in it. Lunberg (1992: 182) says, something contains values if only someone do something according to the values itself understood and has some belongings it.

Then in connection with this, value is said to be the believed of activity of any object, which causes it to be of interest to an individual or group. Living together in group not only can be found in human being has rule, norms, and life values, values can be separated from the enlightening, because value is closely related to the good or bad case.

According to Linda (1997:3), education values generally are divided into two groups:

\subsubsection{Values of Being}

The values of being are a value that is within evolved human beings into the behavior and the way we treats other (1974: 4). Values of being include:

\subsubsection{Honesty}

Honesty toward others, institutions, society, ourselves. Strength and confidence that comes from deep because there was nothing to hide. 


\subsection{Bravely}

Dare to try something good even though it is difficult. Dare to say no to an invitation to err. Dare to follow your good heart in spite of marginalized and suffer from it. Dare to be gracious and friendly. She added the meaning of courage is to do something difficult but correct and is the best option for long term.

\subsection{Peace ability}

Calm and patient attitude. The tendencies to try accept other people's opinions rather than denied and opposed it. Understand that the differences are rarely resolved through conflict and that the obstinacy of a person indicates that he has a problem or feel insecure, and therefore expect your understanding. Willingness to understand other people's feeling instead of reacting to them quickly. Emotional control.

\subsection{Confident and Potential}

Individuality; Awareness of boundaries and the uniqueness of development. Attitude is responsible for his own deeds. Overcoming the tendency to blame others when experiencing difficulties. Believing in ability of self.

\subsection{Self-Discipline and Moderation}

Self-discipline in physical, mentality and financial. Knowing the margin of time talking and eating. Knowing the margin in of strength of body and mind. Consciousness of the dangers in embracing extreme views and impartially. The ability to balance spontaneity with selfdiscipline.

\subsection{Purity and Pureness}

\subsection{Values of Giving}

Purity is clean, without tendency. For example is purity of thinking (Linda, 1997: 80).

The values of giving is that values need to be practiced or provided which would then be accepted as a given. Values of giving include:

\subsection{Loyalty and Trustworthy}

Loyalty toward family, to work, to the State, to the school, and organization and other institutions are responsible to us. Ready to support, ready to serve, ready to help. And trusted and in carrying out consistent promises.

\subsection{Respect}

Respectful toward life, rights, parent, elders, nature and beliefs. Civilized and polite behavior. Respectful to self and avoid detraction to self.

\subsection{Love and Affection}

Love and affection to self which is more than just a loyal and respectful. Dear to friends neighbor who also love to hate us; and emphasizes the lifelong responsibility for saying to the family.

\subsection{Sensitive and Not selfish}

More care to others. Learn to feel togetherness and compassion toward others. Empathy, tolerance and brotherhood. Sensitive to other's needs and situations.

\subsection{Kind and Friendly}

Aware that the friendly and caring attitude is more commendable than the rough and tough attitude. The tendency to maintain instead of confrontation. Tenderness, especially on the younger or weaker. Capable of making new friends and maintain friendship. Lightweight hand to help.

\subsection{Fair}

Obedience to the law, fairness in work and games. The view of the natural consequences and the law of cause and effect. Appreciate the generous and forgiving attitude and understand that revenge is futile. 


\section{RESEARCH METHODS}

In a research, methods one of very important things because guide us to conduct research in properly manner. Therefore, the writer applied appropriate method to get the data accurately. The type of this research belongs to in Descriptive Qualitative. Bogdan and Taylor in Moelong (2002: 4) state that qualitative method as a research procedure, which produces descriptive information in the form of written or oral symbols from people and their behavior which can be observed.

\subsection{Source of the Data}

Source of data is very important thing because all the data that to be analyzed to answer the statement of problem derive from the source of data. There are two types of data sources, namely:

\subsubsection{Primary Data}

Primary data of this research is Novel "Kite Runner" written by Khaled Hosseini which is consists of 324 pages (Enlightening values) published United State of America in 2003.

\subsubsection{Secondary Data}

Secondary data of this research are derived from books and other relevant sources such as internet, outlines, some books, articles and journal about the novel.

\subsection{Technique of Data Collection}

\subsubsection{Documentation}

Creswell (2012: 23) "Documentation consists of public records that qualitative researchers obtain about a site of participant in a study, and they can include newspaper, minutes of meeting, personal journal and letters". There are two types of document; public document and private document. Public document consist of personal journal and dairies, letter, personal notes and joining individual to write themselves.

\subsubsection{Reading}

Reading the novel is the activity of the writer read the novel from the first page until the end of pages; this activity done to collect data from "Kite Runner" Novel by Khaled Hosseini.

\subsubsection{Re-read}

The writer of this study re-read the novel for finding the relevant data focused on the enlightening values in "Kite Runner" Novel by Khaled Hosseini.

\subsubsection{Identifying}

Identifying is established or indicated who or what (someone or something) is. The writer identified enlightening values on the Novel "Kite Runner" by Khaled Hosseini.

\subsection{Technique of Data Analysis.}

\subsubsection{Data Reduction}

Data reduction is the process of selection, concentration on simplification, and rough data transformation that arise from the object research notes.It means that in the data reduction step writer focus to finding important data written by author so that easier to find out enlightening values on Novel "Kite Runner" written by Khaled Hosseini.

\subsubsection{Data Display}

A 'display' is an organize assembly of information that permits conclusion drawing and action taking. The most frequent form of display for qualitative data has been narrative text.

\subsubsection{Conclusion Drawing/Verification}

After the writer analyzed the enlightening values based on the theory stated in chapter two then the last step the research concluded the problem of the research finding in the novel. 


\section{FINDING}

\subsection{Values of Being}

The values of being are a value that is within evolved human beings into the behavior and the way we treats other (1974: 4). Values of being include:

Honesty “Over the years, I had seen a lot of guys run kites. But Hassan was by far the greatest kite runner I'd ever seen. It was downright eerie the way he always got to the spot the kite would land before the kite kid, as if he had some sort of inner compass". (Khaled Hosseini:49)

Almost all religions teach us about goodness and disrepute both of them will bring positive effect and negative, when you are doing the right thing in your life honestly weather action or spoken absolutely the results should be nice. In moslem religion suggested to be honest in everything you do in order to get better life that beneficial for him/her and for other. It has been said that honesty is the best policy. So the honest also will save us from the world and hereafter, so the honest should be taught from early age so that they recognize and feel the result of being honest. Of course, by applying honestly in all fields will increase level of people to the highest one. When we are staying in the village by applying honest, it must become leader.

The writer concluded that the quotation above belongs to honesty because the one of character in the novel his name Amir acknowledge that he has seen one big event that could not easier to get it by ordinary people or young boy but all of sudden young by from lower class of people appeared and able to catch the kite easier. It seldom happen because the young boy with abnormal physic or thin body. He was well-known as slave in this area. But he was lucky in his live staying with very kind man and treated like his son. At seems that Amir as the character in this novel looked the strong the kite runner clearly. It can be seen also from the movie that is why the writer of this study determined that the quotation appropriate with the honesty part of values of being.

Bravely "They're hunting ducks," Ali said in a hoarse voice. "They hunt ducks at night, you know Don't be afraid." (Khaled Hosseini:56)

In ancient time until now that life in the universe has many obstacles, trials, cases and problems faced by human. The higher the knowledge or position the bigger obstacle will be. Therefor those are required to be smart and strong people to get the purpose of life, because each obstacle or problem it has low risk, middle risk and high risk, these are make someone easy to give up surviving their life itself. So, to overcome or minimize the risk people must be strong or brave. Brave it's mean not only brave in acting to do something but also showing his or her skill or ability to solve the problem. Intellectual supported by physically in order everything that they faced can be solved easily.

The quotation above belongs to brave because one of the character in the novel explained about his activities to hunting the animal at the night. This event it seldom happened because it's will take high risk but the character don't care about something will happen to them. Whether the effect of searching the animal good or bad they kept doing it. This quotation belongs to brave.

"I'm sorry Agha sahib, but our bags are already packed. We have made our decision." (Khaled Hosseini:99)

As we know that not all decisions making will bring good effect to the end, people might decide anything eventhough the worse thing it will happen for them they didn't care it (ignore). It's very common this decision making because of they feel under discrimination or be shy it is never considered useful person whether in small group or family. It almost happen between rich people and poor people, well education with low education, different position, 
steal practicing in formal or informal institutions or community. So, it has the opportunity for the high position, high class of people in making decision. Even though will bring negatives effect.

The writer concluded that the quotation above belongs to brave because two of characters in this novel as Ali and Hassan left out from the house suddenly without thinking everything will happen to them in the future. caused of he feel excommunicated in Baba's family. In spite of they are as maid servant or slavery but consistent to went out. In fact both of them were treated the same like son and daughter, son and father and the host was very love them.

\section{"Tell him I'll take a thousand of his bullets before I let this intendancy take place" Baba said." (Khaled Hosseini:107)}

As far as we know the making decision that has taken by high position it's never feel scary at all, it's probably considered himself has power, authority and impunity that is why do anything he wanted. Nowadays, almost whole leader never of thinking deeply to make decision, it will creates demonstration in everywhere because the making decision based on power.

The writer study concluded that the quotation above belongs to brave because Baba as the owner of the house will protect one of the young beautiful woman in the car from security measures. That an un appropriates religion norms in Peace Ability

"Is this about you and Hassan? I know there's something going on between you two, but whatever it is, you have to deal with it, not me. I'm staying out of it." (Khaled Hosseini:83)

As human being needed life harmony, comfortable life understand each other even though different culture, tradition, race, ethnic, believe and religion. Even though it has many differences among us but everyone must appreciate to each other so that everything they will do. they will plan, and will discuss can be decided by properly decision because they respect in every ideas, opinion within small discussion or big discussion to build anything for the public relation. But the societies not only received or agree with every opinion and idea by forcing desire, by high intelligent and logically. In making decision people is required by positive thinking not only self-interest but for public interest.

The writer concluded that the quotation above belong to peace ability because one of the character in this novel name's Baba shows he is someone who loves peace and harmony in daily life. Even though he is someone who is a rich and respectable boss in the area but Baba really upholds a sense of peace. Which is where we can see from this incident when Amir and Hassan had a conflict but Baba didn't interfere in solving their problems. Baba's character is a boss but he never differentiates between his son Amir and Hassan are very loved by Baba.

\subsection{Confident and Potential}

"I didn't know what to think. Or what to say. Was that was it would take? Had he just slipped me a key, I was good kite fighter. Actually a very good one. A few times, I'd made it to the final three." (Khaled Hosseini:52)

The success or failure human in everything that they will do whether for themselves or his self is required smart thinking criticize therefore they will reach the goal of their or his idea fluently. There are many people who have ability skill that supported there idea but they leg self-confident. This potency towards to failure, therefore self-confident or is needed to get everything eventogh they think they will reach difficult to get it, so it's very lucky everyone who has self-confident it's will bring him or her through the success even though the leg of knowledge. Self-confident will have them to corrects is an abilities in presentation his or her ideas.

The writer concluded the quotation above belong to confident and potential because in this story the character name's Amir is a person who really believes in his abilities. He became 
very confident because he had won a kite runner race in his area. Amir told Hassan that he was a very good kite runner in his area. Regardless of what people think and say to him.

4.3.Self-Discipline and Moderation

“When I had finished my mother's book not the boring history ones, I was never much into those, but the novels, the epics I started spending my allowance on books". (Khaled Hosseini:19)

As we know mostly western people is very discipline in the way everything. Events in formal or informal it must be done suitable with the sequence. It's never done do it from top to the bottoms not bottom up. Some example when asking someone about condition the first question began with how are you. Every humans must be has discipline in our behavior such as we must not be late for school, always neatly dressed and always neatly tidy up our book after we read or we study in house or in the school.

The writer concluded that the quotation above belong to self-discipline and moderation because one of the character in this novel name's Amir is a child who is orderly and discipline in all things. In this incident we can see that Amir is very discipline in the tidiness of his belongings and those of other people. Here after Amir read a book written by his mother he tidied up the book and put it on the bookshelf as before.

\subsection{Values of Giving}

The values of giving is that values need to be practiced or provided which would then be accepted as a given. Values of giving include: This part of values of giving which consist of 6 parts but also in this study only found out 3 parts of them appear on the conversation in the novel of the Kite Runner.

\subsection{Loyalty and Trustworthy}

"He put on his gloves again. 'i grew up with ali,"he said through clenched teeth. "My father took him in, he loved Ali like his own son. fourth years Ali's been with my family. Forth goddamm years". (Khaled Hosseini:126)

Long time ago until now the loyalty and trustworthy of someone is needed to increase strong ten and increase relationship In the intuitions whether government or non-government intuitions. In fact many intuitions disperse because there was someone un-loyal towards the leader. This often happened is created by social agency in taking the position, therefore the leader should be evaluated who is appropriate for the high and low position to avoid from fail out.

The writer concluded the quotation above belong to loyalty and trustworthy because one of the character name's Ali as Hassan's father as well as a servant who works with Baba. Ali is very loyal to serve Baba and Amir sons of Baba. In this story Ali has served the Baba's family for nearly 40 years. Not only is loyal to his boss, Baba is a boss who is loyal and friendly to his servants. Because Baba's father took Ali to the house and loved Ali like his own son.

Love and Affection "We did Ayena Masshaf, where they gave us a mirror and threw a veil over our heads, so we'd alone to gaze at each other's reflection, Looking at Soraya's smiling face in the mirror, in the momentary privacy of the veil, I wishpered to her fot the first time that I loved her. A blush, red like henna, bloomed on her cheeks." (Khaled Hosseini:157)

Human being is created by the god in all the world to know each other as they will know story between Adam Hawa as guidance not only for Islam religion but also all religions are needed to believe it hundred person, Romeo and Juliet, Rama and Shinta this popular legend in Indians country most of people believe it from the kids until adults. All these story are created affection by communicate one and others. This affection is to be required understand to each other in all aspect of human life such as a young womens and a young mans having love, parent and son, sisters and brothers, mother and son and than affection friends each other and between 
host and maid servant. In this novel is talking about between high class of people and lower class of people are staying together by equal treatment. He never treated different between son and maid servant caused of His host has affection feeling.

The writer concluded that the quotation above belong to love and affection because two of character in this novel name Amir and Soraya. Amir and Soraya are husband and wife who really love each other. In this incident, when Soraya was looking in the mirror with a smile, the first time Amir told Soraya that Amir really loved her wife's Soraya. Then suddenly Soraya's flushed with embarrassment at the words of her husband's Amir.

\subsection{Kind and Friendly}

“Well, everyone in my school knows what it means," I said. "Let's see. 'inbecile.' It means, intelligent. I'll use it in a sentence for you. When it comes to words, Hassan is an imbecile. “Aaah,” he said, nodding. " (Khaled Hosseini 75: 17)

The environments is very influence towards in human life, most people are living in good environment will created positive in all things. Such as in daily communication, in conversation, and business line it's will respect, appreciate and welcome in everything they will do. Its same to be normal between one and others moreover supported by high level of education or noble men, bad behavior caused of certain environment.

The writer concluded that the quotation above belong to kind and friendly because one eager to know anything that he doesn't know well or uncommon thing. I t will help to get the meaning or function of statement and announcement and to avoid from miss-understanding and miss interpretation. Hassan ask Amir the word that he don't know the meaning and Amir try to help Hassan to find the meaning. Finally Amir explain the meaning of the word that Hassan didn't know.

"Here." He handed me something. "I almost forgot. Happy birthday." it was a brown leather-bound notebook. I traced my fingers along the gold-colored stiching on the borders. I smelled the leather. "for your stories," he said." (Khaled Hosseini: 93)

Humans were created by God in the best possible way. God considers all human beings to be the same, noting more or less. Human are good. Basically all human beings are good. Both in al aspects suchas both parents, teachers, both younger and older people. All humans, nothing bad, all good. Even if there are humans who are bad, it is the choice of the human being themselves. In all religion teachings it is said that all people in this world are good people. If they are not well they may have problems with their life. Therefore we as religious people must be always do good to other's.

The writer concluded that the quotation above belong to kind and friendly because one of the character in this novel name's Rahim Khan as a Baba's friend he don't forget to give gifts to Amir who is 13 years old. In that accident, the Rahim Khan gave a small book to Amir so that Amir could write all of his beautiful writings in the little book. We know that the Rahim Khan is a good person towards Baba and Amir.

"She laughed. "Well, when I was in fourth grade in Kabul, my father hired a woman named Ziba to help around the house. She had a sister in Ira, in Mashad, and, since Ziba was illiterate, she'd ask me to write her sister letters once in a while. And when the sister replied, I'd read her letter to Ziba. One day, I asked her if she'd like to learn to read and write." (Khaled Hoesseini: 139)

As humans we know created by God, we must help each other, both Muslims and nonMuslims. This statement is clearly stated in the hadist. Not only in the teachings of Islam but all religions teach this the same. If we do something good for others one day that goodness will come back to us. We do good without having to look at who the person we will help such as whether he or her a rich person, a poor person, a person of different religions, of different 
ethnicities and so on. But remember we help others must be sincere and without asking for anything in return.

The writer concluded that the quotation above belong to kind and friendly because one of the character in the novel Amir a kind and considerate person. Even though he was a child of a rich and respected person in Kabul. In accident Amir help the servant in his house to read and write the letter to sister who lives in Iran. Because Ziba can't read and write. So, Amir take the initiative to provide assistance to her.

"But I wonder, he added. "would you ever ask me to do such a thing, Amir agha?" and, just like that, he had thrown at me his own little test. If I was going to toy with him and challenge his loyalty, then he'd toy with me, test my integrity. (Khaled Hosseini: $114: 4$ )

Friendship or friends are someone of very important thing as social creature, because we can not stay alone, or selfish and do anything without someone help each other can not separated to get our need. Absolutely we need someone help to share our problem to have the solution, the happiness, sadness, the relationship like this will become someone's yearning. We have to show a friendly to everyone, towards parents, neighbors, friends or to people we don't know. In friendship friendly must be upheld because if we are friendly or kind to others people then automatically that people will be friendly and kind to us. People who are friendly and kind will always be remembered and liked by many people.

The writer concluded that the quotation above belongs to kind and friendly because two of the character in this novel name's Amir and Hassan are best friend when they were little. They love each other and help each other and keep each other. Even though Amir is the son of a rich person but he is very kind and friendly to Hassan, where Hassan is the son of servant who works at his house. Amir is never shy being friends with Hassan. The quotation isexpressing about in a moment unpleasant behavior is shown to other. It is attempted about how long the friendship can be preserve. It's seems the quotation above refer to the enlightening value. The friendship two young boys are from different class of people.

\section{CONCLUSION}

After analyzing and describing data findings deal with enlightening values focused on values of being and values of giving contain in the Novel Kite Runner by Khaled Hosseini. Analyzing in describing lead writer of this study came to the accurately conclusion.

The first one, the writer found out the data finding belongs to values of giving namely there were 2 honest, 5 bravely, 1 peace ability, 2 confident and potential, 1 discipline and moderation. The dominant of data findings there were 5 data found out dealing with bravely.

The second one the writer found out the data finding belong to values of being namely there were 2 loyalty and trustworthy, 2 love and affection, 6 kind and friendly. The dominant of data findings there were 6 data found out dealing with kind and friendly.

Based on the conclusion above that the write of this study concluded that the dominant enlightening values found out bravely part of values of giving, and kind of friendly dominant in part of values of being.

\section{SUGGESTION}

The result of this study expected to well-recognize the theory of enlightening values such values of being and values of giving can be used to analyze not only poem, poetry but also novel such the Novel Kite Runner by Khaled Hoseni.For the teacher, the result of this study to give information that theory of enlightening values can be used for the teaching literature focused on analyzing novel especially extrinsic elements. 


\section{BIBILOGRAPHY}

Anna Muliyana 2015. Tarbiyah and Teacher Training Mataram. An analysis enlightening value in the novel of "Little House in the Big Woods". (Thesis)

Bogdan, Cand Biklen, Knopp. 1982. Qualitative Research for Education. An Introduction to Theory and Method. Bosto: Allyn \& Bacon.

Bogdan, Robbert and Taylor, Steven J, 1975. Introduction of Qualitative Research Method. New York, Brisbane Toronto, Singapore: John Wiley \& Sons.

Hosseini, K, 2001 The Kite Runner: PT. Gramedia

Krippendorf, K. 2003. Content Analysis: An Introduction to It's Methodology, Jakarta: Raja Grafindo Persada.

Linda E. !997. Treaching tour children value today. Jakarta: Gramedia

Linda Eyre and Richard 1997. Describing education and process of education.

Miles dan Hubberman. 1994. Analisis Data Kualitatif.

Ratu Arinda 2017. IKIP Mataram. Enlightening value in the Novel of "Death in the clouds" by Aghata Christy. (Thesis)

Saputra Heru 2012. STAIN. An analysis of Enlightening values in "Rannah 3 Warna" Novel (Thesis)

Sumarjo and Saini (1991: 29). Three genres of novel.

Taylor, Richard. 1981. Understanding of the Element of Literature: New York and London Longman.

Wellek, Rene\&Weren, Austin. 1990. Theory of Literature (di Indonesiakan oleh Melani Budiantara). Jakarta, PT Gramedia.

West.A, 1980 Solid State Chemistry and Its Application. Depatment of Chemistry; New York. 